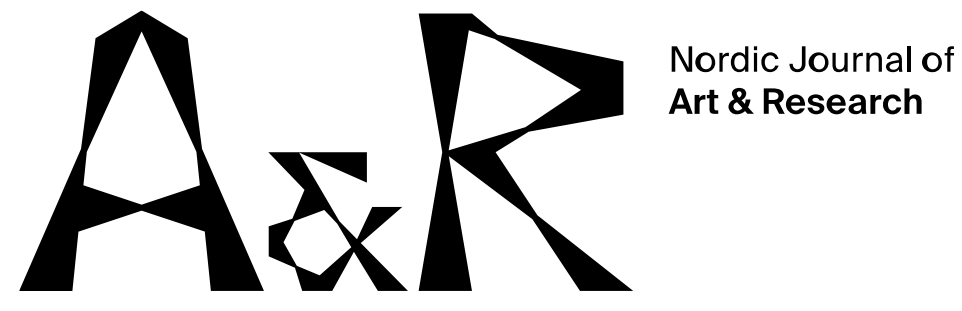

\title{
Knowing Music as Representation or as Operation: Exploring Musical Diversity through Collaborative Music Making in Kaleidoscope
}

\author{
Camilla Kvaal ${ }^{1}$ \\ Inland Norway University
}

\begin{abstract}
A society considered to be in a multicultural condition is likely to condition the way things are seen and what is seen as important. Attention is likely to be drawn to difference and diversity and the prospects of including it, and high hopes may be set on music in this. Within a certain multicultural discourse, music is expected to affirm and represent identities, while at the same time to create unity across diversity. Departing from a Norwegian context, drawing on results from fieldwork within the intercultural ensemble Kaleidoscope, this paper explores collaborative music making in relation to diversity and knowledge production. It is argued that musical knowledge may be generated in useful ways by thinking beyond music as representation. Knowing music as operation may better benefit co-construction of diverse and inclusive music practices.
\end{abstract}

Keywords: Kaleidoscope (Fargespill), collaborative music making, diversity, multicultural music education, musical knowledge 
Camilla Kvaal. Knowing music as representation or as operation

\section{Introduction}

Kaleidoscope (Fargespill) ${ }^{2}$ is a collaborative art project that engages young Norwegians from all over the world in the making of performances based on song and dance that the youngsters themselves bring to the group. A staff of professional musicians and organisers help them deliver spectacular shows to a delighted audience, aiming «to envision the possibilities of diversity through artistic expression» (Stiftelsen Fargespill, n.d.a, my translation). What started in Bergen in 2004 has gradually become an enterprise spreading to other cities and municipalities in Norway. There is a strong belief in the 'Kaleidoscope pedagogy' 3 to promote diversity and inclusion, and politicians as well as pedagogues have embraced the concept. At the time of writing, the Kaleidoscope Foundation ${ }^{4}$ is granted an amount of two million Norwegian kroner in the state budget (Kunnskapsdepartementet, 2020, p. 242). In addition, Kaleidoscope Bergen is granted slightly over one million Norwegian kroner (Kulturdepartementet, 2020, p. 204). The Foundation cooperates with Western Norway University of Applied Sciences on a course on intercultural pedagogy (Høgskulen på Vestlandet, n.d.), and with The Norwegian Council for Schools of Music and Performing Arts (Norsk kulturskoleråd) on licencing the concept to new municipalities (Stiftelsen Fargespill, n.d.b).

In a critical reading of Kaleidoscope's performances, Solomon (2016) suggests that the Kaleidoscope staff uses «the voices and performing bodies of refugee children to tell its story about a supposed Norwegian multicultural utopia» (p. 188). He argues that the performers and their music and dance are «domesticated» (p. 194) as they «participate in a representation of multiculturalism in Norway on Norwegian terms» (p. 201). He insinuates that the group acts on behalf of «white Norwegians» who need to reassure themselves that they are tolerant, and that it serves as a «smoke screen» for the strict refugee policy executed by the Norwegian state. The Kaleidoscope staff has objected to this, not recognizing the picture drawn (Moberg et al., 2016; Pedersen \& Moberg, 2017). Performers have felt that Solomon «stole the credit» from them and gave it to the staff through his assumptions and readings. Supported by musicologist Kvifte (2016), the staff has maintained that what matters

\footnotetext{
${ }^{2}$ Kaleidoscope is the English brand name for Fargespill. Fargespill means 'colour play' or 'play of colours' in Norwegian.

${ }^{3}$ According to one of the founders, Kaleidoscope never thought of what they do as a pedagogical method. They are nevertheless amused by the fact that professional educators have named it so. ${ }_{4}^{4}$ The Kaleidoscope Foundation (Stiftelsen Fargespill) comprises Kaleidoscope Oslo in addition to the group in Bergen (Stiftelsen Fargespill, n.d.b).
} 
to knowledge production and inclusion of diversity happens not on stage, but during the collaborative process. I will contend that they all have a valid point (see also Kvaal, 2017, 2018). As I will show, collaborations and negotiations backstage relate to discourses permeating international and national cultural policy that adhere to the multicultural aphorism of unity in diversity. I will argue that prevailing multicultural commitments to recognize and represent cultural identities may condition the way music is seen and what is expected from it, exemplified by what seemed to be at stake in Kaleidoscope. It is likely that a musical ontology (cf. Bohlman, 1999) emerges that I will call music-as-representation, which bears a certain view of musical diversity and inclusion. I find it promising to bring attention to another way of seeing music that I will call music-as-operation, which may allow engagement in how music functions in various ways along algorithmic processes. Moving from music-asrepresentation to music-as-operation may have implications for music education and the production of musical knowledge, as well as for inclusion of diversity. A question I want to pose throughout the paper is: What is there to know and learn considering musical diversity? I will not attend to the question by attempting to provide specific answers. Rather, I will show how invoking music-as-representation or music-asoperation may imply different answers to the question in terms of what counts as musical knowledge.

The following discussions draw on results from fieldwork carried out by the author within Kaleidoscope Bergen between 2014-2015 (see Kvaal, 2018). The data were generated by observing the group's activities during rehearsals and performances, both on-stage and back-stage. Also, semi-structured individual interviews with twelve young performers and musicians (henceforth, 'performers') and five employees and leaders (henceforth, 'staff') were conducted. ${ }^{5}$ The interview questions were designed to generate articulations of musical experiences and preferences, delights and difficulties during rehearsals, as well as what they achieved from participating in the project. Further, a group interview with all the seven employees was conducted and

\footnotetext{
5 In Kaleidoscope's terms, those referred to as 'performers' were the young singers and dancers joining the group. Some also played instruments and had a somewhat unclear status at the time of the fieldwork, whether they «belonged» to the orchestra of professional musicians or to the group of nonprofessional performers. Some leaders were employed by the Kaleidoscope Foundation and others were older performers in a kind of limbo between performer and staff member. Throughout this paper I use 'staff' for the artistic leaders and other employees and 'performers' for singers, dancers and musicians not employed. The reader should be aware that this does not necessarily fit with the terms used within Kaleidoscope.
} 
Camilla Kvaal. Knowing music as representation or as operation

official documents describing Kaleidoscope were analysed. Studying how music and dance was negotiated, I found various strategies for learning and making music. Music-as-representation seemed to be prominent in advocacy of the project. However, music-as-operation seemed to be equally at stake in musical negotiations.

I start the following discussion by attending to aspects of multicultural discourse as discussed by various scholars addressing educational and postcolonial issues within the field of cultural studies. I proceed by indicating how Norwegian cultural policy emerges in relation to global international efforts, setting the stage, so to speak, for ensembles like Kaleidoscope. Presenting data from the fieldwork, I point to how musical diversity seemed to be at stake and what kinds of musical knowledge that seemed to be suggested within the group. Eventually, I consider what viewing music as representation or as operation might imply for knowledge of musical diversity and inclusion thereof. Throughout the discussion, I bring in theoretical perspectives that may contribute to a possible reconditioning of the multicultural and a change of scope regarding musical knowledge.

\section{Different, different, but same: conditioning music in (multi)cultural studies}

Bohlman (2012) maintains that music «underwent an ontological transformation of proportions» (p. 30-31) during the time of imperial encounters. To missionaries and colonial officers, «[m]usic represented culture in two ways: as a form of expression common to humanity, and as one of the most extreme manifestations of difference» (p. 31). He further notes that music is continuously attached to identity narratives of national belonging and displacement, which I find, accordingly, to be a crucial premise for the multicultural condition to which I attend.

Discussing the emergence of multicultural education in the United States, Pratte (1981) notes a discrepancy between cultural diversity as a condition and cultural pluralism as an ideology. Though diversity may be a fact, he writes, pluralism is a goal not yet achieved and which does not necessarily follow from the circumstances. How it can be reached, if it should be reached, and what it implies philosophically is not unanimous, though there is a common strive towards mutual recognition and understanding, he maintains. However, Pratte remarks the conundrum in this, in line with several others (e.g. Bhabha, 1994/2004; Gran, 2002; Gressgård, 2007; Grossberg, 2010; Henningsen, Berkaak \& Skålnes, 2010; Taylor, 1994): Total relativism in granting universal rights to every particular group or thinkable person is unachievable, as various traditions or wishes for life simply do not go together peacefully. According to Taylor (1994), a multiculturalist ethics of recognition rests on 
Camilla Kvaal. Knowing music as representation or as operation

the idea of a universal human potential «for forming and defining one's own identity, as an individual, and also as a culture» (p. 42). A right and plight to be different stands in a peculiar alliance with the plight to secure universal rights for everyone. $A$ frequent multicultural approach according to Taylor is to locate a common standard that allows equal judgement and recognition. The subsumption of differences under one principle (a taxonomic paradigm of diversity according to Berkaak (2012)) underpins, as I see it, aphorisms such as though we are different, we are all human beings or though we are different, we all have an identity. The idea of such a standard, Taylor (1994) maintains, nevertheless implies an ethnocentric view that passes judgement before one knows what is at stake for other people.

To speak of the multicultural supposes, I would say, that all are united as cultural beings, for instance, put in vernacular, that all «have a cultural background». Though ubiquitous, 'culture' is seldom clearly defined and appears to be self-evident, as Middleton (2012) notes. He underscores that there are plenty of contradictions and tensions regarding how scholars in the field of cultural studies explain culture and how it matters, though all agree that it does. However, the most influential strand according to Middleton is «the theories emphasizing culture as the sphere of meaning, of collective symbolic discourse, webs of significance, processes of signification; ... the dimension in which humans interpret their activities» (p. 7) moreover, culture as text. Hence, when discussing musical meaning it implies an interpretation of what it represents. In a student textbook on representation, Hall (1997, p. 3) writes: «Meaning is what gives us a sense of our own identity, of who we are and with whom we 'belong' - so it is tied up with questions of how culture is used to mark out and maintain identity within and difference between groups» (Hall, 1997, p. 3). He holds that music is a 'system of representation', which constructs, transmits and carries meaning, though in sophisticated and complex ways. ${ }^{6}$ Thus, I find multicultural 'recognition' to have a double meaning: both to understand musical messages and to affirm identities carried and constructed through them. Put in taxonomic aphorisms: Though we are different, we all represent culture or though music is different, it represents cultural identities.

Pratte (1981), among others, disputes a tendency to treat cultural identity as stuck in the past: «[B]eliefs must be treated as beliefs, not like quaint ethnic gems - the

\footnotetext{
${ }^{6}$ Hall has provided the field of cultural studies in music with, in my opinion, brilliant and inspiring theorization on identity that is widely referred to. Nevertheless, this 'explanation of the basics' reveals an issue I am questioning in the course of this article.
} 
sacred relics of previous generations» (p. 10). As I understand him, he argues for the possibility as well as the obligation to account for change, both from within and without a cultural group, and that the relativistic challenge of multicultural coexistence is only a paradox insofar as cultures are considered to be static. In Bhabha's (1994/2004) view, national representation is a constant process of contestation. Though there is a strong move towards a unifying narrative of a people, the people is constantly split by daily negotiations and differential activities: «The problem is not simply the 'self-hood' of the nation as opposed to the otherness of other nations. We are confronted with the nation split within itself, articulating the heterogeneity of its population» (p. 212). Thus, a nation is rather a dissemi-nation, according to Bhabha. Furthermore, a similar rupture is disseminating individual identification processes. As «the subject of desire is never simply a «Myself», the Other is never simply an It-self, a front of identity, truth or misrecognition» (Bhabha, 1994/2004, p. 74). The multicultural enterprise to identify with, to distinguish against, to tell stories of who 'we', 'they' or 'you' and 'l' are, is a constant process of negotiation within and without. Hall (1996) notes that identity is a process of becoming, concerning «not 'who we are' or 'where we came from', so much as what we might become, how we have been represented and how that bears on how we might represent ourselves» (p. 4).

However refined the thinking tools, it seems to me that music and culture for Hall and many of his colleagues still boils down to representational narratives of identities, as «[i]denties are ... constituted within, not outside representation» (p. 4). Accordingly, musical knowledge entails knowing what, whom and how it represents, by interpretation. Spivak (1988) highlights confusion regarding the notion of representation. There are two aspects of it that are frequently conflated: to represent in terms of 'to stand in for' or 'give voice to', and to re-present, as in 'describe' or 'make a portrait of'. These are important to keep in mind as two different notions, she cautions, even though they might relate to each other. This adds another analytical layer to the double meaning I have noted earlier, dealing with 'recognition' as both understanding and affirmation. Her concerns regarding subaltern possibilities to speak, or as much Western abilities to listen, raises additional issues regarding the question of agency in music-as-representation, as I will show in my analysis of music making in Kaleidoscope.

\section{Norwegian cultural policy and its conditions}

A multicultural agenda to ensure both the right to be diverse in terms of cultural heritage and the right to be equal can be said to underpin articulations of international human rights. The UNESCO Convention of the Safeguarding of 
Camilla Kvaal. Knowing music as representation or as operation

Intangible Heritage (UNESCO, 2003/2018) puts cultural heritage forward as «a vehicle for identity and social cohesion» (p. v), «a mainspring of cultural diversity» ( $p$. 3 ) as well as «a factor of bringing human beings closer together and ensuring exchange and understanding among them» (p. 4). Seemingly, conflicting ways of life distils to «the phenomenon of intolerance» (p. 3). That there may be potential conflicts and power relations between, or even within, groups, is not considered. The UNESCO convention on the Protection and Promotion of the Diversity of Cultural Expressions (UNESCO, 2005) states that «the diversity of cultural expressions ... allows individuals and peoples to express and to share with others their ideas and values» and that «cultural activities ... convey identities, values and meanings» (p. 2). Culture as narratives representing identity seems to be the prevailing ontology traversing international legislation, as well as in mainstream cultural studies.

However, while the contributions within cultural studies tend to emphasise cultural difference through a critical lense of power relations, the UNESCO conventions seem overly optimistic on behalf of the ease with which people can reach mutual understanding and amity through their various cultural expressions. Contrary to many recent cultural theorists, the conventions seem to value cultural heritage as mainly static and oriented towards the past. By ratifying the conventions, like Norway did in 2006 (Ministry of Culture, 2020), states commit themselves to raising awareness of and building capacities for the sustention of cultural heritage and cultural diversity through education and other areas of state policy. An imperative to treat culture as representation will, I suspect, be sneaking in through the backdoor. Henningsen et al. (2010) maintain that UN reports and conventions have influenced Norwegian cultural policy considerably. Definitions and arguments are practically «downloaded» and taken for granted as a rationale, at the state level and among local practitioners, even though the claims about cultural diversity may be contested.

Norwegian policy makers are inclined to entrust music (and art and culture in general) with powers to solve a variety of societal problems, as noted by Røyseng and Varkøy (2014). Several projects have been organized and financed by the Norwegian state and municipalities to include artists with immigrant background in the field of art and culture, and to make people more open to culturally diverse expressions (see Kvaal, 2018, s. 238-247 for a discussion on previous efforts as a backdrop for Kaleidoscope, e.g. the Resonant Community project (Klangrikt fellesskap) (Skyllstad, 1993; Bergh, 2007)). Notwithstanding, evaluative research has deemed the efforts mostly futile, largely due to outdated terminology as well as insufficiently articulated, and hence, conflicting, ambitions (e.g. Baklien \& Krogh, 2002; Bergh, 2007; Berkaak, 2002; Gran, 2002; Henningsen et al., 2010). No less, the optimistic view on culture is reaffirmed in the recent white paper The power of 
Camilla Kvaal. Knowing music as representation or as operation

culture: Cultural policy for the future (Ministry of Culture, 2018): «Art and culture are able to unite people across opinions, interests and backgrounds» (p. 14). I find the multicultural paradox of unity in diversity to permeate the white paper, accompanied by an implicit notion of culture as representation. In recent years, a certain definition of art and culture ${ }^{7}$ as expression has been fortified, considering it a democratic issue related to freedom of speech:

[C]ultural activities provide schooling in participation in the community of disagreement that is a prerequisite for a viable democracy. They help develop a competence in expressing oneself that covers each individual's preferred cultural expressions and forms of these and is also about dealing with new experiences and the tastes and expressions favoured by other groups and individuals. (Enger et al., 2014, cited in Ministry of Culture, 2018, p. 13)

'Expressive culture'8 is expected to contribute to a 'community of disagreement' ${ }^{9}$, in which different groups and individuals prefer different artistic expressions. Cultural heritage is evoked as both expressions of and tools for identity and democracy. According to the white paper, minorities will thus be able to «establish their own public arenas» and be given «a chance to be heard in the broader society and communicate with it», as artistic and cultural expressions "represent voices and experiences» (p. 15). The power of culture seems to waver between powers to split and powers to unite. Further, music as expressive culture that «represent[s] voices and experiences» seems to waver between expressions as made by and belonging to identities to be accepted and affirmed, in which a democratic conversation would take place about music, and narrative expressions to be understood, in which a democratic conversation would take place in music. The latter seems to be

\footnotetext{
${ }^{7}$ In this document, as in the Norwegian policy field in general, art and culture are used somewhat interchangeably.

${ }^{8}$ The notion 'ytringskultur' [expressive culture] was coined «in order to give substance and distinction to the notion of culture for cultural policy, without identifying culture as a given, predefined content» (Enger et al., 2013, p. 14). In my opinion it is questionable, though, whether identifying culture as expressions is not delimiting, especially the way it is linked to opinions.

9 The notion 'uenighetsfellesskap' [community of disagreement] has been coined by Iversen (2014). It echoes Mouffe's (2013) 'agonistic society', though in the vernacular use of the word, this dimension is somewhat diluted. Though Iversen's aim is to counter the notion of community as shared values, it seems like agreement lingers as the important feature of the policy described in the white paper, disagreement being more of a challenging backdrop.
} 
Camilla Kvaal. Knowing music as representation or as operation

accompanied by a conviction that musical messages will be understood, as «[a]rt can reflect reality in ways that foster a shared understanding and bring us closer to the truth» and even "give us insight that we cannot achieve otherwise» (p. 12). Spivak's (1988) concern to separate proxy and portrait is highly relevant to bear in mind, in order to locate different layers and aspects of representation and thus to avoid confusion when considering democratic agency and the alleged power of culture.

The credos in the white paper bear striking resemblances to advocative statements put forth by Kaleidoscope: «Music and dance make it clear: how obvious it its that we are the same, and how enriching it is that we are different» (Hamre \& Saue, 2012, p. 20). The multicultural aphorism of unity in diversity is recognizable, connected to music and dance as identity narratives imbued with self-explanatory truthfulness.

Everyone has a story to tell, and the sum of these stories is the story of us all. The deeply subjective story of one of us is at the same time universal. And the only arena where this story can be told and understood in all its complexity, complete with its paradoxes and wealth of information, is in art. [...] This is the storytelling we, and all artists, strive towards. (Hamre, 2012, p. 55)

The way the founders of Kaleidoscope see it, the audience may be educated by the performances «through seeing and hearing living examples of how our separate experiences can be combined into something that is a product of us all» (Hamre, 2012 , p. 52). The strategy of combining music and dance from different parts of the world echoes a widespread enthusiasm for hybridity and musical fusion, which according to Ellingsen (2007) has been something close to a «state policy» for diversity and inclusion in Norway and the rest of Scandinavia (for a discussion on intercultural music as hybrid music, see Kvaal, 2017, 2018). Hence, Kaleidoscope does not happen in a vacuum. In the following, I enquire into how musical practice and decisions in Kaleidoscope may be said to relate to the multicultural backdrop I have indicated, and how I find the idea of cultural diversity tied to representation to be unable to explain what is going on.

\section{Music-as-representation in Kaleidoscope: envisioning diversity, voicing diversity}

The following text promoting Kaleidoscope indicates that music and dance is seen to represent the performers, as well as where they come from: 
Camilla Kvaal. Knowing music as representation or as operation

On stage, you meet children and young people aged 7-25 from different parts of the world. Everyone has a different background, history and identity. ... [T] he performances are based on what the performers bring of cultural treasures by form of songs and dances, often mixed with each other and with so called global youth culture, like hip hop and beatboxing. ... The result is performances that yield a close, musical encounter with young people's history of whom they are, revealed through music and dance from where they grew up. (Stiftelsen Fargespill, n.d.a, my translation)

Song and dance will «reveal» who the performers are, and who they are seems linked to where they grew up. The Kaleidoscope staff has maintained, though, that they do not expect their performers to represent nationalities or ethnicities, but rather «to approach people as individuals and ... encourage them to bring in songs that are meaningful to their lives» (Pedersen \& Moberg, 2017, p. 48). This seems however to be at odds with the promise of «cultural treasures» "from where they grew up», at least potentially. Bringing to mind Spivak's (1988) double notion of representation, I find both forms of representation to be present, as two sides of the same coin, encapsulated in "young people's history of whom they are». Kaleidoscope aims to show diversity on stage through vision and sound, to picture it through artistic means. The project also seeks to give youth a voice and to make those voices heard. They are allowed to, and expected to speak of themselves and for themselves through music and dance. I elaborate on how I see the two forms of representation to be at play.

In a teaser for one of their shows (Fargespill, 2015), Kaleidoscope has presented an array of clips from the performance. By intervals of four to eight seconds the viewer is quickly brought from one piece to the next. People are dancing, singing, playing instruments, crowding on stage or performing solo. There are colourful lights, ethnic costumes and people with varying amounts of melanin under their skin. Energetic music is heard, presumably from different corners of the world. Watching makes me wonder what kinds of differences I am witnessing. Is it possible for a random spectator like me to know? For sure, there are markers, both visual and aural that might be picked up as differences. The spectacle may come forward as diverse, but what the particular differences are all about, I presume is left to personal imagination. My own watching experience could be summed up by a well-known Monty Python catch phrase: «And now for something completely different...!» It seems like difference is made a point in itself, but exact differences seems indifferent. This way of «envisioning» diversity can be related to representation as description: An 
Camilla Kvaal. Knowing music as representation or as operation

impression is made of different people, different features, different music, different cultures - and different stories.

Related to this concern, the leaders emphasised that the performers should «own» the performances, which I connect to a democratic notion of representation. The methods used during the making and rehearsal of the shows have, to an everincreasing extent, been to consult the performers on how they want their music and dance to be. They want the performers to be experts of their own contributions. Nonetheless, the supporting staff of professionals is ascribed a competence that the young performers do not have: They know what would work on stage.

The idea is that powerful scenic communication depends on both strong stories and top-level professionality. Highly qualified composers, musicians, choreographers, light and sound designers, scenographers and instructors take care of the professional frame, and inside this frame the kids and the youth give of themselves (byr på seg selv), their culture and history. (Stiftelsen Fargespill, n.d.a, my translation)

What would work on stage, implies what would work for the audience. What would work for the audience, seems to follow the double logic of music as representation: there are musical messages to be understood and identities to be recognized. The founders of Kaleidoscope maintain that the audience acquires knowledge from the performances as an instant, emotional insight: «Not like the summation of a list of pros and cons, or the tally of verbal direct hits in a political debate. But rather the broad and deep intuition of the blessings of diversity» (Hamre, 2012, p. 52). The acclamation given to the performers in return, seals a mutual appreciation and understanding. Throughout the interviews and observations, I found audience reactions to be a significant theme. Negotiations over the music and dance often drew arguments from what they thought the audience would like or expect from the group (or as often from what they would not like, in terms of getting bored or upset, for instance). Several of the performers highlighted the staff's knowledge as invaluable, as did this performer:

Researcher: Why do you think the people... why do you think the audience cry when they see your show?

Performer: Well, we have such a fantastic management. They understand and they study the audience, and [know] that in this situation, this is the best song to play, right? We have such people, really smart. For instance, when we sing that «Ja, vi elsker» [the Norwegian national anthem], in a 
way, it shows that, when they hear it from people who are really not Norwegian, right, it actually tells that we represent the same values and stuff like that. (Interview with performer 01.02.2015)

There is an understanding that the show can be produced to assure a representation that the audience will recognise, in the double meaning of the word. The Kaleidoscope staff has a difficult task. They want to take care of the performers and make their voices sound by taking care of what they bring to the group. They also want to take care of the performers and make their voices heard by making the audience attentive toward them, and the audience will be attentive if they like what they see and hear, and if they think they understand it.

It's a process, you know... and for those who don't know that process, it can be a bit frustrating, because they give away something that they clearly know by their inner ear, how it should be. And then we have to walk that road together. [...] In this song, it's mostly about drums and singing. When the musicians enter, there will be another sound, maybe different from what they have imagined. We are approaching a tune that at the same time keeps [Performer]'s song, dance, but at the same time it will be presented to an audience in a professional frame. So, it needs to be a dialogue with the one who brought the song. And mostly it all falls into place. By and by. (Interview with staff 14.10.2014)

In light of this, it is possible to discern that there may be more to diversity than impressions of diverse sights and sounds, and that there is more happening backstage than of which the audience is aware. The assumption that meeting the youth on stage will make the audience acquainted with the performers' stories or that they will learn about diversity suddenly seems more doubtful. Revisiting the dispute between Solomon (2016) and Kaleidoscope, it seems that both staging and negotiations take place, as the negotiations relate to the staging.

\section{Welcoming 'space invaders'}

There was yet another side to diverse representation with which the Kaleidoscope staff was concerned. They pondered why the audience did not reflect the diverse music and people on stage. They had noticed that there were mainly White families and White elderly women coming to see the shows. Was it due to economy? To lack of information? Was it due to a general exclusion from the arts by an elite? The staff was attentive to these matters and frequently used the metaphor «crossing the 
Camilla Kvaal. Knowing music as representation or as operation

threshold to Grieghallen ${ }^{10} »$. One of the participants shed some light on this, explaining why s/he had been sceptical about a piece they were rehearsing previously:

Researcher: What did you imagine could be bad? Was it about how you sang, or would it be about that it wasn't [ethnic group] enough, or that it wasn't...?

Performer: No, not that it wasn't [ethnic group] enough. But that it wasn't, that the combo didn't sound particularly good. That it [wouldn't] catch the audience, because that is in a way what we want. We want to reach out to people with our message and all that. And then it's important to think about what can make the audience go «woo!», you see, you can't take all your wishes into account, maybe, but you have an idea about, not like, I don't mean to think stereotypically, but maybe Norwegians like this, and Tamils and Kurds, that you need to think a bit like that before you just... yeah. (Interview with performer, 03.02.2015)

According to this performer, the song and dance could be arranged in ways that would attract different audiences, perhaps other audiences than the one the staff had in mind, that was probably likely to cross the threshold in the first place. The thought of addressing different audiences was common among the performers. They delighted in including various styles in their shows, «so that everyone can listen to it and like it» (Interview with performer, 23.03.2015). In this case, viewing the song and dance as a «message» to understand, not merely appreciate, seems to complicate the situation.

Ahmed (2012) regrets that diversity is frequently seen as inclusion of different people, essentially those who «look different». Accordingly, signs of diversity are that a group contains, by appearance, bodies of different colour, gender, sexual orientation, religion and so forth. Puwar (2004) has coined the metaphor space invaders to describe people who show up a in place they usually do not «belong». There are no explicit rules that exclude them, and they might even be specifically welcomed, in the name of diversity. The way space invaders stir attention and surprise by their presence, reveals, nevertheless, that there are intrinsic mechanisms defining them as outsiders. Puwar holds that awareness of the presence of 'out-of-place bodies' is

10 Grieghallen is a Concert hall in Bergen. 
Camilla Kvaal. Knowing music as representation or as operation

valuable as it reveals that something is taken for granted about participation in that place.

I want to entertain the metaphor of space invaders. I say that what Kaleidoscope aims to do in terms of diverse musical encounters is beautifully captured by the message on this guerrilla cross-stitch embroidery kit to be purchased on Etsy (Figure 1).

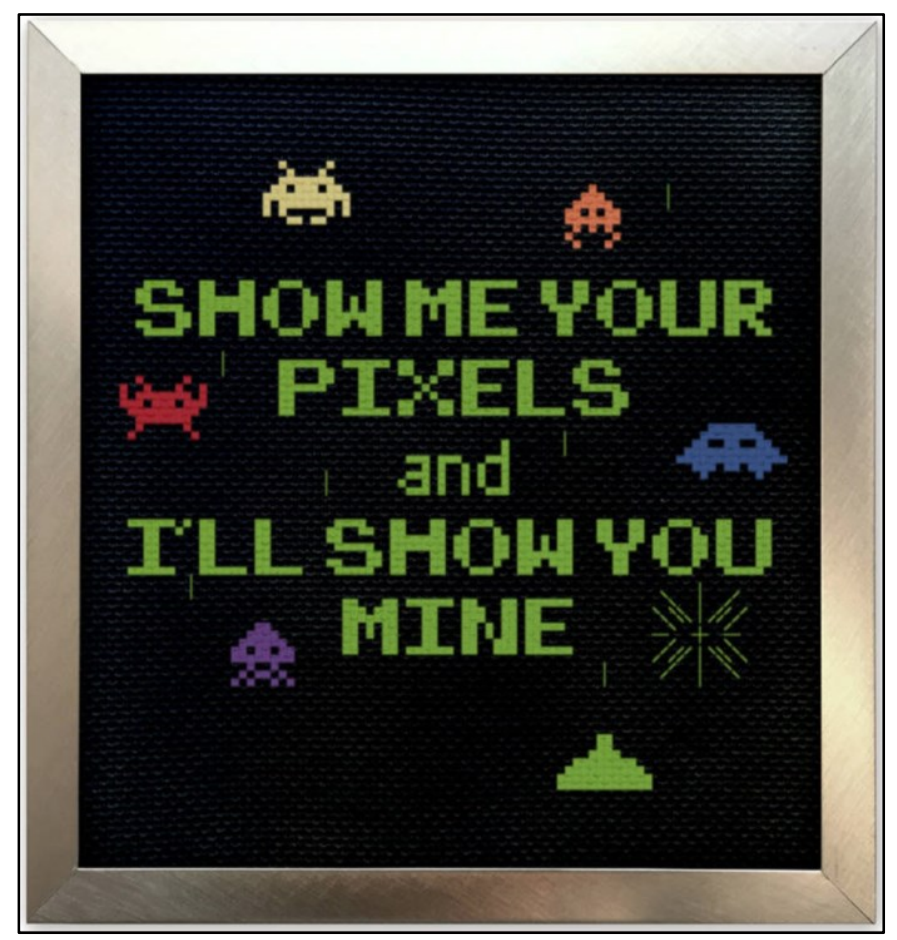

Figure 1. 'Show me your pixels' by CatvsCute, n.d

By focussing on how the Space Invaders characters consist of pixels, a multicultural representational game of mutual recognition can be played: Show me your pixels and I'll show you mine. Identities and cultural backgrounds are pictured, or pixelated, in the music. By showing music and dance, life stories are envisioned. Pixel by pixel, element by element of music and dance is combined to show who people are and how they go together. Diversity is seen to exist peacefully side by side in this way of representation: Though we are different, we all have pixels.

However, the real game of Space Invaders is played like this (Figure 2): 


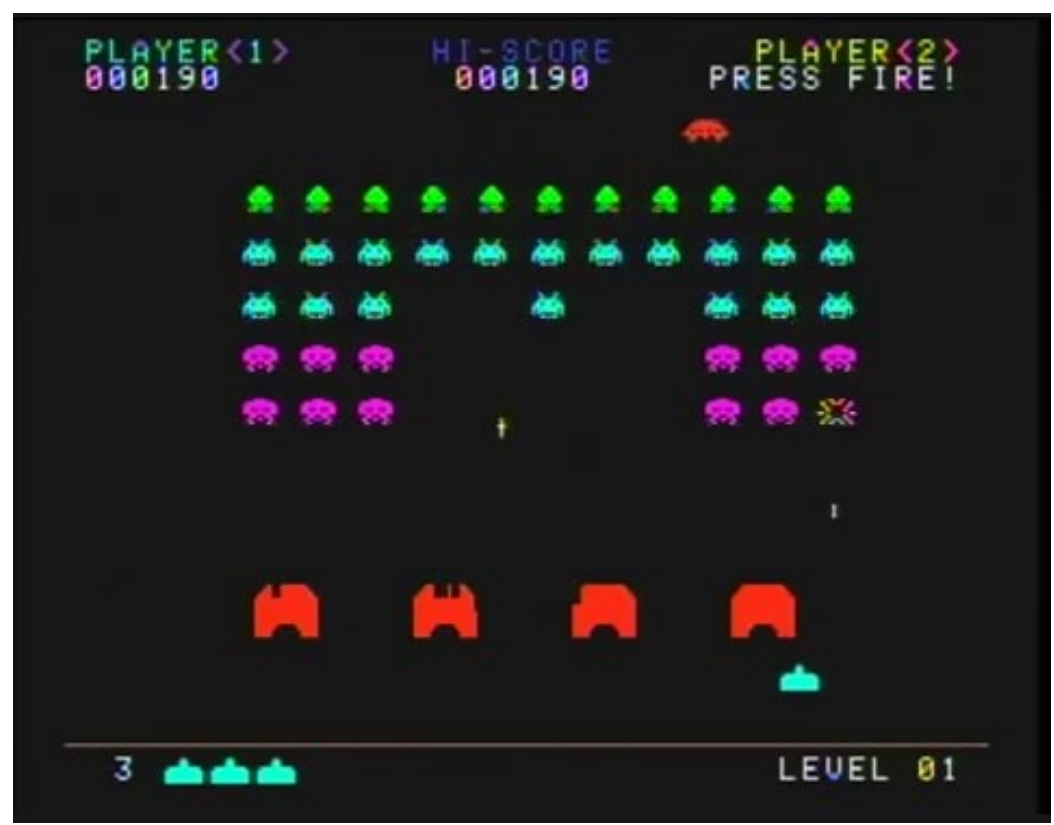

Figure 2. Space Invaders. Click for animation. (gif courtesy of Gfycat, 2017)

Pixel by pixel threatening invaders are hunted down as they approach the fortresses. In this case, I find algorithms to be at stake rather than pixels. An algorithm can be explained as «a set of rules that precisely defines a sequence of operations» (Stone quoted in Algorithm, 2020). To effectively eliminate the aliens, one has to spot the logics of their movements, of their beings. A tender game of exchange would rather be: Show me your algorithms, and I'll show you mine. Puwar (2004) points to the fact that there are scripts for gestures, movements and speech patterns connected to identities. I will add musical gestures. Space invaders are encouraged to minimise signs of difference, or at least the signs that may be threatening. They have to «whitewash» their interests and ways of being. Keeping a space White, male, straight, or Black, female, queer or, for that sake, middleclass, or belonging to other group affiliations, demands hard work, and this work is not necessarily a conscious enterprise. Such tasks are exactly for what institutions are good. Institutions are fortresses built to expel invaders, or rather expel invasive operations. That is why, as Ahmed (2012) points out, institurions are not universal and open, even if people working in institutions believe they are, or would like them to be. Musical gestures and patterns, the algorighms at work that come forward as pixels, are welcomed as signs of cultural difference. That which does not comply with the operational system must be translated: a syntax error. The moment they threaten to destroy crucial workings of the operative system, possibly leading to an alienation of those whom the institution were built to protect, they must be disarmed and made harmless. 
Camilla Kvaal. Knowing music as representation or as operation

In Kaleidoscope, the exchange of diverse music and dance is frequently expressed in the metaphor of a warm welcome. To purchase a doormat like this on eBay and put it in front of the threshold would nevertheless be futile (Figure 3).

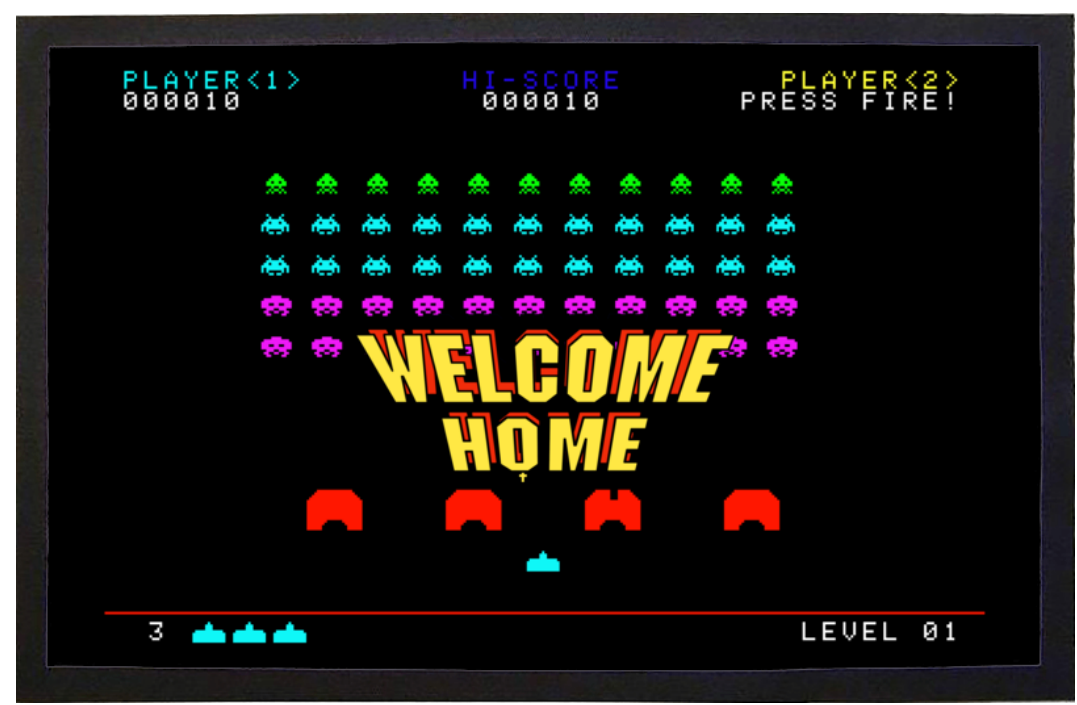

Figure 3. A «welcome home» mat available on eBay, n.d.

To cross the threshold demands operating one's way inside. Due to the real game of Space Invaders, aliens are bound to an eternal alienation, and hence to an eternal welcome. When music and dance is tailored to 'the audience', they are kept in place by a relevant, touching and understandable show. People noticed as out of place, however welcome as they might be, bear witness to the reality that the place is not established for them. A multicultural exchange based on music-as-representation easily overlooks how diversity is grounded in operations. Puwar writes: «lf we are to move beyond banal versions of diversity which simplistically count the heads of 'different' bodies in organisations, then our tools of analysis need to engage in indepth ethnographic research within institutions» (Puwar, 2004, p. 77-78). That is, it is necessary to enter the deep web of institutions to know how to include difference. In the following, I elaborate on how I see this in relation to music and how I found it to be at work in Kaleidoscope.

\section{Music-as-operation: working (out) diversity}

By paying attention to algorithms, music and dance can be seen as operations. Gilbert Simondon's (1958/2017) description of technical operations and technical objects may be fruitful for such a musical analysis. In the following quote, Simondon writes about machines, but I have replaced it with music for the sake of demonstration: 
Camilla Kvaal. Knowing music as representation or as operation

Man's presence to [music] is a perpetuated invention. What resides in the [music] is human reality, human gesture fixed and crystallized into working structures. The structures need support during their course of operation, and the greatest perfection coincides with the greatest openness. (p. 18)

Though Simondon describes machines, this bears a striking resemblance with art, in the sense of generating new experiences:

$[E]$ ach piece, in the concrete ${ }^{11}$ object, is no longer simply that which essentially corresponds to the accomplishment of a function desired by the [music maker], but a part of a system where a multitude of forces act and produce effects that are independent of the fabricating intention. (p. 39)

Such unforeseen effects and possibilities may generate joy or irritation. To create objects, like music and dance, to do music, is a continuous and persistent struggle to keep desired functions, and of course to experience new ones. Musically speaking, there are playing rules, musical logics and projects at play. Following Simondon, I aver music is human gestures fixed and crystallized into structures that work - or do not work - for the different people involved. When music is combined in Kaleidoscope, there may be a lot going on in this respect, as noted by one of the performers:

Researcher: How does it work [when that song is combined with the other one]? Do you think... does it fit, the way you hear the song, or is it... strange?

Performer: Well, I have been thinking a lot about that. Because when I hear the other songs, I think «wow, this is awsome!» But when I hear my own songs, then (laughs), for instance [Song], I'm not really that pleased with it, like, well, of course, it is very good, but um... I feel like much of the atmosphere in the song is eh, killed, because a Western «boom-takachack-taka-ding-ding-t» is inserted, while it used to be «dinga takka-ta-gadinga-dinga-takka-takk». [...] When they don't use that rhythm, you lose

\footnotetext{
${ }^{11}$ A concrete object, according to Simondon, is an object that is made to function in desired ways, not standing in the way of its own functioning by conflicting operations.
} 
Camilla Kvaal. Knowing music as representation or as operation

much of the atmosphere, because it's very.. It's just like the spinal bone marrow of the song's music, that rhythm. I have tr-, eh, well, thought of telling [Leader], but I feel that would be very rude, because [Kaleidoscope] is about mixing a bit here and there, but, um, what I.. I think it's OK to mix, there is nothing wrong with that, but it would have been extra pleasurable with that rhythm. (Interview with performer 03.02.2015)

Combining music is thus not just adding one pixel to the other. Music operates, operation upon operation, and one operation can put another to a halt. When experiencing combinations of unknown music, or music other than one's own, possible discrepancies may go unnoticed. This little space invader, or at least a pixel of it, was actually killed and did not make it across the threshold to the stage in Grieghallen. I find it worthwhile to ask for what reason. For the sake of the audience's recognition, maybe, or for the sake of envisioning diversity? Or, simply, because someone actually did not know? If the involved musicians knew the operational difference like the performer knew it, maybe it would have been possible to keep the atmosphere and the spinal bone marrow by keeping the desired algorithms, the playing rules that mattered. A further question is whether that would feel alien to an audience, or how it might be possible to do it in a way that exited them.

According to Ahmed (2012), valuable knowledge is produced by attempts to enter an institution from the outside, crossing the threshold to Grieghallen being a case in point: «[E]ach new strategy or tactic for getting through the wall generates knowledge of what does or does not get across» (Ahmed, 2012, p. 175). My studies show that because diversity looks different from different angles, one can not be immediately certain that diversity really is brought up on stage. By exploring musical negotiations in terms of musical operations, it is possible to learn something about the institutional mechanisms and moreover how it may be possible to make music - and people cross the threshold. To open up an institution is to allow into the system new aims and ways of reaching them. With this in mind, Grossberg's rearticulation of agency is a useful one:

[M]arginalization is not a spatial position but a vector defining access, mobility and the possibilities of investment. The question of agency is, then, how access and investment or participation (as a structure of belonging) are distributed within particular structured terrains. At the very least, this suggests that agency as a political problem cannot be conflated with issues of cultural identity or of epistemological possibilities.

(Grossberg, 1996, p. 10) 
Camilla Kvaal. Knowing music as representation or as operation

It is necessary to look beyond the notion of identity and representation to understand what it may imply to know and include musical diversity.

\section{Reconditioning the multicultural}

I started this discussion by explicating a certain multicultural discourse conditioning musical practice. Much scholarly work has been done to refine tools for thinking identity and culture. Still, a prevailing perspective in cultural theory as well as in cultural policy and practice, like the investment in Kaleidoscope, seems to be that the relationship between music and identities is a representational one, and hence that this is what musical knowledge is all about. Being both the same and different, or feeling both the same and different, can be considered an important feature of multicultural identity constitution. However, the experience may be hard to pinpoint through the lens of music-as-representation.

Simondon (1965/2015) offers a definition of culture that I find very useful: Culture is «the ensemble of techniques of direct human manipulation that each human group employs to perpetuate its own stability» (p. 18). This has quite many implications for the thinking of music and group affiliations, and it involves a notion of the transindividual. The transindividual implies not just how individuals relate to each other, but how they relate «through what they invent» (Simondon, 1958/2017, p. 252), for instance through music and dance. Music and dance may thus be thought as transindividual significations, as I have suggested elsewhere (Kvaal, 2018). Transindividual significations are operational as much as they are representational.

According to Simondon (1958/2020), group dynamics, or groupalisation, happens at the level of affectivity. The motor of grouping processes is the desire to feel the same way, he maintains. To feel good or bad about the same, to value the same, makes us the same. I would say it makes us the same, and it also makes us the same, though only for a processual moment. It demands a lot of work to stay together as a group through certain ways of musicking, and to keep other ways at bay. Algorithms operate and make people feel, and they challenge their being. The way I see it, Simondon's perspective adds a layer to Bhabha's (1994/2004) notion of dissemination, in that identity processes can be seen as grounded in operations, not necessarily narratives. A musical event is thus an operational zone, sometimes a combat zone, where negotiations between individuals in a never-ending process create and adjust to themselves and their environment. They are at the same time moving closer to and apart from each other - through the music. Hence, music is not just a representational symbol. To communicate about music is more than to analyse of whom it bears witness or to whom it belongs. It is to grasp and adjust to how it 
Camilla Kvaal. Knowing music as representation or as operation

functions as well as how these functions may be adjusted. To make music is to experiment with the viable and the meaningful. It might be embraced by others, and it might not. Attention to the operational dimension allows finding solutions on how to work together.

In light of this, Ahmed's (2004) caution that feelings should not be considered a learning outcome becomes paramount. In my opinion, the actual learning potential is not the enigmatic experience of feeling the same though different. The potential lies in frustrating obstacles which, when worked out together, may eventually lead to understanding, companionship and feelings of togetherness, which seemed to happen quite often through the 'Kaleidoscope pedagogy', though not all the time. There is a rub, however. The knowledge that may bring music over the threshold and up on stage, is not instantly available to or recognised by an audience. When music and dance rich with aural and visual markers of diversity ostensibly unite, it may feel enigmatic, and it is possible to delight in the sensation of magic. Still, I would call it an illusion - unless one starts looking for algorithms instead of pixels.

A steering question throughout this paper has been: What is there to know and learn considering musical diversity? This is an open question, and an accumulating one, as difference is constantly produced, not just discovered, through encounters. However, I will claim that a shift from music-as-representation to music-as-operation can be a game changer regarding musical difference and how to know and include diversity. Attending to music-as-operation can even support music-as-representation, by deliberately sidestepping identity narration and moving the attention from telling stories of who people are to exploring what they can do together.

\section{About the author}

Camilla Kvaal is an Associate Professor at Inland Norway University of Applied Sciences, lecturing in music teacher education on BA and MA levels. She is a member of the research group Music Education and Cultural Studies. Kvaal's research interests are philosophy of music and music education as well as intercultural music making. In 2018 Kvaal defended her PhD thesis Kryssende musikkopplevelser: En undersøkelse av samspill $i$ en interkulturell musikkpraksis (Musical junctions: An exploration of joint musicking in an intercultural music practice). Based on fieldwork with the group Fargespill (Kaleidoscope), Kvaal discussed intercultural music making and emancipatory music education in light of Gilbert Simondon's philosophy. 
Camilla Kvaal. Knowing music as representation or as operation

\section{References}

Algorithm. (2020, February $13^{\text {th }}$ ). In Wikipedia. Retrieved February $15^{\text {th }}, 2020$, from https://en.wikipedia.org/wiki/Algorithm

Ahmed, S. (2004). The cultural politics of emotion. New York: Routledge.

Ahmed, S. (2012). On being included: Racism and diversity in institutional life. Durham: Duke University Press. https://doi.org/10.1515/9780822395324

Baklien, B. \& Krogh, U. (2002). Evaluering av Mosaikk: Et program under Norsk kulturråd. Oslo: Norsk kulturråd.

Berkaak, O. A. (2002). Fri for fremmede: En evaluering av signalprosjekt Open Scene. Oslo: Norsk kulturråd.

Berkaak, O. A. (2012). De andres mange ansikter: Mangfold i tanker, ord og gjerninger. Norsk antropologisk tidsskrift, 23(1): 66-75.

Bergh, A. (2007). l'd like to teach the world to sing: Music and conflict transformation. Musicae Scientiae, 11(2), 141-157. https://doi.org/10.1177/10298649070110S207

Bhabha, H. (1994/2004). The location of culture. London: Routledge.

Bohlman, P. V. (1999). Ontologies of music. In N. Cook \& M. Everist. (Eds.), Rethinking music (p. 17-34). Oxford: Oxford University Press.

Bohlman, P. V. (2012). Music and culture: Historiographies of disjuncture, ethnographies of displacement. In M. Clayton, T. Herbert \& R. Middleton (Red.), The cultural study of music: A critical introduction (2 ${ }^{\text {nd }}$ edition) (p. 2839). New York: Routledge.

CatvsCute. (n.d.) Show me your pixels Space Invaders arcade pixel - cross stitch pattern. Retrieved February $15^{\text {th }} 2021$, from https://www.etsy.com/au/listing/560212363/show-me-your-pixels-spaceinvaders

DeNora, T. (2013). Music asylums: Wellbeing through music in everyday life. Burlington: Ashgate.

eBay. (n.d.). Retro gaming \& space inspired invaders design welcome home doormat. Retrieved February $15^{\text {th }}, 2021$, from https://www.ebay.co.uk/itm/183896466476

Ellingsen, A. (2007). Music and ethnic integration in Norwegian state politics (Doctoral thesis). University of Oslo, Oslo.

Enger, A., Berdahl, G., Eriksen, A., Hungnes, T., Nåvik, E., Campos, C. L. ... Stavem, E. (2013). Kulturutredningen 2014. (NOU 2013:4). Oslo: Departementenes servicesenter, Informasjonsforvaltning. Retrieved from https://www.regjeringen.no/no/dokumenter/nou-2013-4/id715404/ 
Camilla Kvaal. Knowing music as representation or as operation

Fargespill [Kaleidoscope]. (2015, December $\left.22^{\text {nd }}\right)$. Teaser fra forestillingen «Fargespill-Real Ones» [Videoclip]. Retrieved from https://www.youtube.com/watch?list=RDDW7WCogoHJY\&v=DW7WCogoHJY

Gfycat. (2017, September 20th). Atgames Atari flashback 6: Space Invaders GIF. Retrieved February 15th, 2021, from https://gfycat.com/distantillinformedboutu

Gran, A. B. (2002). Mosaikk - når forskjellen forener: Evaluering av programmet for kunst og det flerkulturelle samfunn. Oslo: Norsk kulturråd.

Gressgård, R. (2007). 'Det beste fra to kulturer': Frihet og fellesskap. In $\varnothing$. Fuglerud \& T. H. Eriksen (Eds.), Grenser for kultur? Perspektiver fra norsk minoritetsforskning (p. 80-110). Oslo: Pax Forlag.

Grossberg, L. (1996). Identity and cultural studies: Is that all there is? In S. Hall \& P. du Gay (Eds.), Questions of cultural identity (p. 87-107). Los Angeles: SAGE. https://doi.org/10.4135/9781446221907.n6

Grossberg, L. (2010). Cultural studies in the future tense. Durham: Duke University Press. https://doi.org/10.1515/9780822393313

Hall, S. (1996). Introduction: Who needs identity? In S. Hall \& P. du Gay (Eds.), Questions of cultural identity (p. 1-17). Los Angeles: SAGE. https://doi.org/10.4135/9781446221907.n1

Hall, S. (1997). Introduction. In S. Hall (Ed.), Representation: Cultural representation and signifying practices (p. 1-11). London: SAGE.

Hamre, O. (2012). The Kaleidoscope philosophy. In O. Hamre \& S. Saue (Eds.), Kaleidoscope, (p. 52-57). Bergen: Kaleidoscope.

Hamre, O. \& Saue, S. (Eds.). (2012). Kaleidoscope. Bergen: Kalieidoscope.

Henningsen, E., Berkaak, O. A. \& Skålnes, S. (2010). Mangfoldsåret: Muligheter og motsigelser i politikken for et flerkulturelt kulturliv (NIBR-rapport 18, 2010). Oslo: Norsk institutt for by- og regionsforskning. Retrieved from https://evalueringsportalen.no/evaluering/mangfoldsaaret-muligheter-ogmotsigelser-i-politikken-for-et-flerkulturelt-kulturliv

Høgskulen på Vestlandet [Western Norway University of Applied Sciences]. (n.d.). IKP801 Interkulturell pedagogikk og fargespillmetodikk. Retrieved from https://www.hvl.no/studier/studieprogram/emne/33/ikp801

Iversen, L. L. (2014). Uenighetsfellesskap: Blikk på demokratisk samhandling. Oslo: Universitetsforlaget.

Kulturdepartementet [Ministry of Culture]. (2020). Prop. 1 S (2020-2021): Proposisjon til Stortinget (forslag til stortingsvedtak). Retrieved from https://www.regjeringen.no/no/dokumenter/prop.-1-s-20202021/id2768407/ 
Camilla Kvaal. Knowing music as representation or as operation

Kunnskapsdepartementet [Ministry of Education]. (2020). Prop. 1 S (2020-2021):

Proposisjon til Stortinget (forslag til stortingsvedtak). Retrieved from https://www.regjeringen.no/no/dokumenter/prop.-1-s-20202021/id2768541/

Kvaal, C. (2017). Crossing affordances: Hybrid music as a tool in intercultural music practices. In Ø. Varkøy, E. Georgii-Hemming, A. Kallio \& F. Pio, Nordisk musikkpedagogisk forskning. Årbok 18 (p. 117-132). Oslo: Norges Musikkhøgskole.

Kvaal, C. (2018). Kryssende musikkopplevelser: En undersøkelse av samspill i en interkulturell musikkpraksis [Musical junctions: An exploration of joint musicking in an intercultural music practice] (Doctoral thesis). Inland Norway University of Applied Sciences, Hamar.

Kvifte, T. (2016, October 19th). Fargespill og eksotifiserende akademikere.

Ballade.no. Retrieved from http://www.ballade.no/sak/fargespill-ogeksotifiserende- akademikere/

Middleton, R. (2012). Introduction: Music studies and the idea of culture. In M. Clayton, T. Herbert \& R. Middleton (Red.), The cultural study of music: A critical introduction ( $2^{\text {nd }}$ edition) (p. 1-14). New York: Routledge.

Ministry of Culture. (2018). The power of culture: Cultural policy for the future [summary]. (Meld. St. 8 2018-2019). Retrieved from https://www.regjeringen.no/contentassets/9778c28ab1014b789bbb3de0e25e0 d85/en-gb/pdfs/stm201820190008000engpdfs.pdf

Ministry of Culture. (2020, July $\left.2^{\text {nd }}\right)$. UNESCO. Retrieved from https://www.regjeringen.no/en/topics/culture-sports-and-non-profitwork/innsiktsartikler/International-cooperation/UNESCO/id766556/

Moberg, F., Pedersen, A. E., Hamre, O., Saue, S., Tunestveit, S. R., Berge, K. \& Guino-o, E. (2016, October 17th). Ja til god forskning om Fargespill. Ballade.no. Retrieved from http://www.ballade.no/sak/ja-til-god-forskning-omfargespill/

Mouffe, C. (2013). Agonistics: Thinking the world politically. London: Verso.

Pedersen, A. E. \& Moberg, F. (2017). Response to Thomas Solomon's article "The play of colors: Staging multiculturalism in Norway". Danish Musicology Online, 8, 45-52. Retrieved from http://www.danishmusicologyonline.dk/arkiv/arkiv dmo/dmo 08/dmo 08 artik el 04.pdf

Pratte, R. N. (1981). Multicultural education: A need for philosophical perspective. World Education Monograph Series (3), Retrieved from https://files.eric.ed.gov/fulltext/ED216961.pdf 
Camilla Kvaal. Knowing music as representation or as operation

Puwar, N. (2004). Thinking about making a difference. The British Journal of Politics and International Relations, 6, 65-80. Retrieved from https://doi.org/10.1111/j.1467-856X.2004.00127.x

Røyseng, S. \& Varkøy, Ø. (2014). What is music good for? A dialogue on technical and ritual rationality. Action, Criticism, and Theory for Music Education, 13(1), 101-125. Retrieved from http://act.maydaygroup.org/articles/RøysengVarkøy13 1.pdf

Simondon, G. (1958/2020). Individuation in light of notions of form and information. Minneapolis: University of Minnesota Press.

Simondon, G. (1958/2017). On the mode of existence of technical objects. Minneapolis: Univocal.

Simondon, G. (1965/2015). Culture and technics. Radical Philosophy (189), 17-23. Retrieved February $15^{\text {th }}, 2021$, from https://www.radicalphilosophyarchive.com/issuefiles/rp189 article2 simondon culture and technics.pdf

Skyllstad, K. (1993). Rikskonsertenes innvandrerprosjekt Klangrikt Fellesskap 19981992. Evalueringsrapport. Oslo: Rikskonsertene; Universitetet i Oslo.

Solomon, T. (2016). The play of colors: Staging multiculturalism in Norway. Danish Musicology Online Special Edition. 17 $7^{\text {th }}$ Musicological Congress 2016, 187201. Retrieved from

http://www.danishmusicologyonline.dk/arkiv/arkiv dmo/dmo saernummer 201 6/dmo saernummer 2016 NMC 10.pdf

Spivak, G. C. (1988). Can the subaltern speak? In C. Nelson \& L. Grossberg (Eds.), Marxism and the interpretation of culture (p. 271-313). Urbana: University of Illinois Press. https://doi.org/10.1007/978-1-349-19059-1 20

Stiftelsen Fargespill [Kaleidoscope Foundation]. (n.d.a). Hele verden på én scene. Retrieved 15th of February 2021, from https://fargespill.no/om-fargespill/ Stiftelsen Fargespill [Kaleidoscope Foundation]. (n.d.b). Fargespill $i$ andre byer. Retrieved February 15th, 2021, from https://fargespill.no/fargespill-lisenser/ Taylor, C. (1994). The politics of recognition. In A. Gutman (Ed.). Multiculturalism: Examining the politics of recognition, (p. 25-73). Princeton: Princeton University Press.

UNESCO. (2003/2018). Basic texts of the 2003 convention for the safeguarding of the intangible cultural heritage, 2018 edition. Paris: UNESCO. Retrieved from https://ich.unesco.org/doc/src/2003 Convention Basic Texts- 2018 versionEN.pdf 
Camilla Kvaal. Knowing music as representation or as operation

UNESCO. (2005). Convention on the protection and promotion of the diversity of cultural expressions. Paris: UNESCO. Retrieved from https://unesdoc.unesco.org/ark:/48223/pf0000142919

UNESCO. (s.a.). The UNESCO collection of traditional music of the world. Retrieved from https://ich.unesco.org/en/collection-of-traditional-music-00123 